\title{
Clinical Stage III Esophageal Squamous Cell Carcinoma AJCC v8
}

National Cancer Institute

\section{Source}

National Cancer Institute. Clinical Stage III Esophageal Squamous Cell Carcinoma A/CC v8. NCl Thesaurus. Code C133450.

Stage III includes: (T3, N1, M0); (T1-3, N2, M0). T1: Tumor invades the lamina propria, muscularis mucosae, or submucosa. T2: Tumor invades the muscularis propria. T3: Tumor invades adventitia. N1: Tumor with metastasis in one or two regional lymph nodes. N2: Tumor with metastasis in three to six regional lymph nodes. M0: No distant metastasis. (AJCC 8th ed.) 